\title{
Biodegradation of Household Waste Using Micro- Organisms For Production of Important Products
}

\author{
Anita M Chandak ${ }^{1}$ and Rupali Balpande ${ }^{2}$ \\ ${ }^{1}$ D.R.B. Sindhu Mahavidyalya Nagpur, Maharashtra India \\ ${ }^{2}$ Kamla Nehru Mahavidyalaya, Nagpur, Maharashtra India Corresponding author email: chandakmb@gmail.com
}

\section{ABSTRACT}

Household waste generated in towns has emphasized on the area for research due to increasing concern about pollution ecosystem and human health. Everyday a huge quantity of waste materials generated from houses. Various type of waste causing adverse effect on living organisms and environment that giving rise to human as well as animal diseases , spoilage in air and soil ecosystem lead to total imbalance in natural ecology. Aerobic biodegradation of organic matter by microbes (aerobes) is most rapid and fast degradation process. No pungent gas produced. Large disposable waste generated. The present study showed vegetable waste was rich source of enzymes, carbohydrates, fats, moisture and phytochemicals and best substrate for Microbial Biodegradation purpose. Analysis of individual enzymatic activity of mixed microbial species on household waste and production of industrially important products.

\section{KEY WORDS: BIODEGRADATION, CELLULASE, AMYLASE, MICROBIAL CONSORTIA.}

\section{INTRODUCTION}

Biodegradation is the process by which organic substances are broken down into smaller compounds by the enzymes produced by living microbial organisms. The microbial organisms transform the substance through metabolic or enzymatic processes. Biodegradation processes vary greatly, but frequently the final product of the degradation is carbon-dioxide or methane. Organic material can be degraded aerobically with oxygen or anaerobically without oxygen. The microbial population of soil possessed mainly bacteria, fungi, actinomycetes, algae and protozoa. Among these groups, bacteria are most prominent and abundant group. Bacteria use waste for their own metabolism and finally they produce hazardous toxic chemicals into non-toxic or less toxic substances which are important for soil health, plant growing and over all to keep well balance of natural ecosystem.

The genera Bacillus, Corynebacterium, Staphylococcus, Streptococcus, Shigella, Alcaligens, Acinetobacter,

Biosc Biotech Res Comm P-ISSN: 0974-6455 E-ISSN: 2321-4007

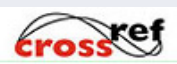

Identifiers and Pagination

Year: 2021 Vol: 14 No (9) Special Issue

Pages: 291-298

This is an open access article under Creative

Commons License Attribn 4.0 Intl (CC-BY). DOI: $h t t p: / / d x$.doi.org/10.21786/bbrc/14.9.54
Escherichia, klebsiella and Enterobacter were the best hydrocarbon degrading bacteria.Mixed microbial communities have the most powerful biodegradative potential because the genetic information of more than one organism is necessary to degrade the complex mixture of organic compounds present in contaminated areas (Bird et al., 1954; Bruckner 2016).

Fungi are an important part of degrading micro biota because like bacteria they metabolized dissolved organic matter, they are principle organisms responsible for the decomposition of carbon in the biosphere. But fungi unlike bacteria can grow in low moisture areas and low $\mathrm{pH}$. Solutions which aids them in the breakdown of organic matter. Filamentous fungi participating in aliphatic hydrocarbons degradation are Cladosporium and Aspergillus whereas a fungus belongs to penicillin; Fusarium and Aspergillus can take part in aromatic hydrocarbon decomposition (Chapman et al., 1999).

\section{MATERIAL AND METHODS}

1) Sterilization of All glassware's and culture media were sterilised in an autoclave for 15 minutes.

2) Preparation of Sieved Sample of Vegetables waste, then determine the physical parameters of sieved sample of vegetable waste such as colour, weight, $\mathrm{pH}$, temperature, and moisture and water absorption capacity.

\section{Article Information}

Received: 09 $9^{\text {th }}$ June 2021 Accepted after revision: $25^{\text {th }}$ July 2021 
3) Isolation of Bacteria: The Bacteria were isolated using standard serial dilution of soil and sewage water sample and characterised using the specificity of the substrate and gram nature of the organism. They are maintained on Nutrient agar slant at $4^{\circ} \odot$ for further use.

4) Isolation and collection of fungi: Aspergillus niger was isolated from onion skin on Potato dextrose agar. The plate were incubated for 5-7 days at $28^{\circ} \odot$. Black colonies of Aspergillus niger was maintained on potato dextrose agar at $4^{\circ} \odot$.The collected pure culture of Trichoderma viride, Bacillus subtilis were maintained on selective media and subculture on Sabouraud dextrose agar slant individually at $4^{\circ} \odot$ (Gautam et al., 2012).

5) Screening of Amylase Activity (Starch Hydrolysis Test: In this test, starch agar is inoculated with bacteria and fungi. After incubation at an appropriate temperature, iodine is added to the surface of the agar. Iodine turns blue-black in the presence of starch. Absence of the blueblack colour indicates that starch is no longer present in the medium (Gautam et al., 2010).

6) Screening of Cellulase Activity: Cellulase-producing bacteria and fungi were inoculated by the streak plate method using Carboxy methyl cellulose agar media. The plates were incubated at 37 degree centigrade for 24 hours for bacteria and 3-4 days for fungi at $37^{\circ} \odot$. The plates were flooded with $0.1 \%$ of Congo red solution for $15 \mathrm{~min}$ and washed with $1 \mathrm{M} \mathrm{NaCl}$, and the zone of hydrolysis was recorded. The zone of hydrolysis shows positive test (Indumathi 2017).

7) Preparation of microbial consortia: Take three test tubes containing $5 \mathrm{ml}$ nutrient broth and inoculate loopful of pure culture of selected microbes separately and incubate for 37degree centigrade for 24 hours. Transfer $3 \mathrm{ml}$ (1-1-1) of 24 hour grown nutrient broth in $27 \mathrm{ml}$ freshly prepared broth that is equal to $30 \mathrm{ml}$. Again incubate the $30 \mathrm{ml}$ broth for $24 \mathrm{hr}$ and store for further use (Ingale et al., 2014).
8) Preparation of experimental test samples (N, $\mathrm{BC}, \mathrm{ABC}, \mathrm{FC}, \mathrm{AFC}$ ) and enzymatic activity assayed calorimetrically.

9) Estimation of Amylase activity :( DNSA 3,5Dinitrosalicylic acid method).

\section{Procedure:}

a) $\quad 1 \%$ starch solution was prepared for performing the test.

b) $1 \mathrm{ml}$ of $1 \%$ starch solution and different dilutions of extract of enzymes along with $1 \mathrm{ml}$ of citrate phosphate buffer was incubated for 30mins at 50 $\circ \odot$

c) $2 \mathrm{ml}$ of DNS solution was added to stop the reaction.

d) Tubes were kept for boiling in water bath for 10 minutes.

e) Absorbance was recorded at 540 $\mathrm{nm}$ against glucose standard.

The amount of enzyme, which releases 1 micromole of reducing sugar as glucose per minute is called as one unit of enzyme activity.

10) Estimation of Cellulase activity:

Procedure:

a) $1 \%$ of carboxy methyl cellulose was prepared

b) $\quad 0.45 \mathrm{ml}$ of the above was taken as a substrate and incubated with $0.05 \mathrm{ml}$ of enzyme extract

c) $\quad 0.05 \mathrm{ml}$ of Citrate Phosphate buffer was added to it and incubated at $55 \mathrm{C}$ for 15 minutes.

d) $\quad 0.5 \mathrm{ml}$ DNS was added to stop the reaction and kept in boiling water bath for $5 \mathrm{~min}$

e) Absorbance was recorded at 540nm against standard glucose.

11) Assay of total protein by Folin-Lowry method

Table 1. Determination of Physical Parameters of Test Samples
\begin{tabular}{l|c|c|c|c|}
\multirow{2}{*}{ Test } & \multicolumn{4}{|c|}{ SampleRate Of Degradation In gm/ Moisture Content In gm/day } \\
\cline { 2 - 5 } & $7^{\text {th }}$ & $14^{\text {th }}$ & $21^{\text {st }}$ & $28^{\text {th }}$ \\
\hline \multirow{2}{*}{ 1) $\mathrm{N}$} & $80 / 3.2 \mathrm{gm}$ & $60 / 5.6 \mathrm{gm}$ & $28 / 6.7 \mathrm{gm}$ & $18 / 7 \mathrm{gm}$ \\
\hline 2) $\mathrm{BC}$ & $96 / 3.8 \mathrm{gm}$ & $58 / 6.1 \mathrm{gm}$ & $41 / 4.5 \mathrm{gm}$ & $32 / 3.3 \mathrm{gm}$ \\
\hline 3)ABC & $100 / 4 \mathrm{gm}$ & $93 / 3.7 \mathrm{gm}$ & $53 / 5.8 \mathrm{gm}$ & $47 / 4 \mathrm{gm}$ \\
\hline 4) FC & $93 / 3.7 \mathrm{gm}$ & $85 / 3.4 \mathrm{gm}$ & $72 / 2.8 \mathrm{gm}$ & $41 / 1.6 \mathrm{gm}$ \\
\hline 5)AFC & $100 / 4 \mathrm{gm}$ & $86 / 3.4 \mathrm{gm}$ & $66 / 2.6 \mathrm{gm}$ & $46 / 1.8 \mathrm{gm}$ \\
\hline
\end{tabular}

Procedure: Into a series of test tubes pipette out $0.2 \mathrm{ml}$ to $1 \mathrm{ml}$ working standard solution (concentration between 20 to $100 \mathrm{ug}$. Makeup unknown sample solution to 50ml distilled water and pipette out $0.5 \mathrm{ml}$ into a test tube. Add $\mathrm{NaOH}$ to all tubes to make up volume uniformly to $1 \mathrm{ml}$. Pipette out $1 \mathrm{ml} \mathrm{NaOH}$ into a separate tube to serve as blank. To all tubes add $5 \mathrm{ml} \mathrm{ml}$ alkaline copper reagent. Mix well and incubate at room temperature for 10 minutes. Into all the tubes pipette out $0.5 \mathrm{ml}$ of Folin's - Ciocalteau Reagent, mix well reaction contents and incubate at temperature $37^{\circ}{ }^{\circ}$ of for 30 minutes Measure absorbance of color blue formed calorimetrically 
at $750 \mathrm{~nm}$. The intensity of color is directly proportional to amount of protein present in sample. Draw a standard calibration curve by plotting the concentration of protein on $\mathrm{X}$ - axis and the absorbance on Y-axis. Calculate the concentration of unknown protein from the graph.
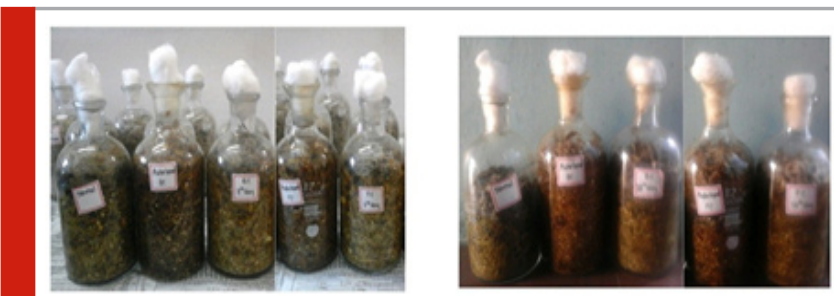

Figure: Rate Of Degradation Within 28 Days Of Incubation Period
12) Assay of Free Reducing Sugars by 3, 5 -Dinitrosalicylic Acid Method. Same as amylase activity assay.

13) Estimation of Total an Antioxidant Capacity by Phosphomolybdenum Method (Janarthanan et al., 2014).

Procedure: The tubes containing $0.2 \mathrm{ml}$ of extract (100$1000 \mathrm{ug} / \mathrm{ml}$ ) is mixed with, $1.8 \mathrm{ml}$ of distilled water, 2 $\mathrm{ml}$ of phosphomolybdenum reagent solution. Incubate it at $95^{\circ} \odot$ for 90 minutes. The mixture is cooled to room temperature and the absorbance is measured at $695 \mathrm{~nm}$ against a reagent blank. The antioxidant capacity is expressed as Ascorbic Acid Equivalent (AAE).

\begin{tabular}{|c|c|c|c|c|}
\hline Enzyme Activity & Substrate & $\begin{array}{l}\text { Name Of } \\
\text { Microbe s }\end{array}$ & Observations & Results \\
\hline \multirow[t]{4}{*}{ Amylase Activity } & Starch Agar & Escherichi a coli & $\begin{array}{l}\text { Clear Zone Of Inhibition } \\
\text { Was Not Observed After } \\
\text { Addition Of Iodine } \\
\text { Solution }\end{array}$ & Negative \\
\hline & & Bacillussubtilis & $\begin{array}{l}\text { Clear Zone Of } \\
\text { Inhibition Was } \\
\text { Observed After } \\
\text { Addition OfIodine } \\
\text { Solution }\end{array}$ & Positive \\
\hline & & $\begin{array}{l}\text { Aspergillus } \\
\text { niger }\end{array}$ & $\begin{array}{l}\text { Clear Zone Of } \\
\text { Inhibition Was Not } \\
\text { Observed After } \\
\text { Addition Of Iodine } \\
\text { Solution }\end{array}$ & Negative \\
\hline & & $\begin{array}{l}\text { Trichoderma } \\
\text { viride }\end{array}$ & $\begin{array}{l}\text { Clear Zone Of } \\
\text { Inhibition Was Not } \\
\text { Observed After } \\
\text { Addition Of Iodine } \\
\text { Solution }\end{array}$ & Negative \\
\hline \multirow[t]{3}{*}{$\begin{array}{l}\text { Cellulase } \\
\text { Activity }\end{array}$} & $\begin{array}{l}\text { Carboxy } \\
\text { methyl } \\
\text { Cellulose } \\
{[\mathrm{CMC}]}\end{array}$ & Escherichia coli & $\begin{array}{l}\text { Clear Zone Of } \\
\text { Inhibition Was } \\
\text { Observed After } \\
\text { Addition Of Congo } \\
\text { Red Dye Solution }\end{array}$ & Positive \\
\hline & & Bacillussubtilis & $\begin{array}{l}\text { Clear Zone Of } \\
\text { Inhibition Was } \\
\text { Observed After } \\
\text { Addition Of Congo } \\
\text { Red Dye Solution }\end{array}$ & Positive \\
\hline & & $\begin{array}{l}\text { Aspergillus } \\
\text { niger }\end{array}$ & $\begin{array}{l}\text { Clear Zone Of } \\
\text { Inhibition Was } \\
\text { Observed After } \\
\text { Addition Of Congo } \\
\text { Red Dye Solution }\end{array}$ & Positive \\
\hline
\end{tabular}

\section{Experimental Results}

\section{Results and Discussion:}

1. Estimation of Amylase activity

\section{Estimation of Cellulase activity}


Table 3. Standard Glucose concentration curve

\begin{tabular}{|l|c|c|}
\hline Test Tube & $\begin{array}{c}\text { Standard Solution } \\
\text { Of Glucose (ug/ml) }\end{array}$ & $\begin{array}{c}\text { Optical Density } \\
\text { (At 540 Nm) }\end{array}$ \\
\hline 1 & 0 & 0.00 \\
\hline 2 & 200 & 0.13 \\
\hline 3 & 400 & 0.26 \\
\hline 4 & 600 & 0.40 \\
\hline 5 & 800 & 0.51 \\
\hline 6 & 1000 & 0.64 \\
\hline
\end{tabular}

Figure: 1: Standard Glucose Concentration Curve

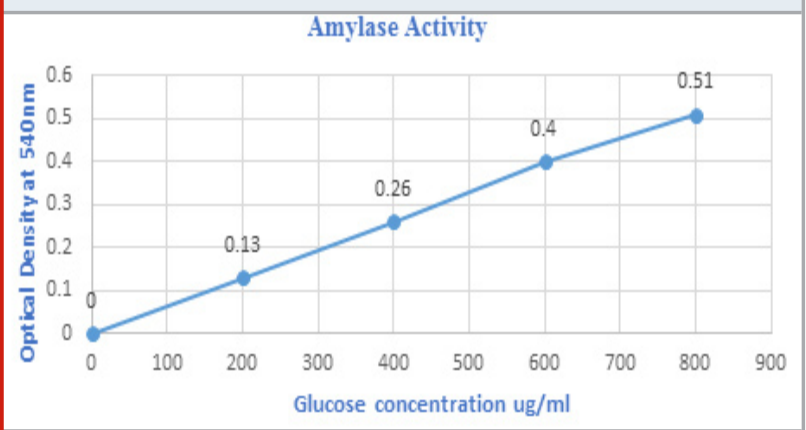

Table 4. Amylase Activity Chart

\begin{tabular}{l|c|c|c|c|}
\hline \multirow{2}{*}{$\begin{array}{l}\text { Test } \\
\text { Sample }\end{array}$} & \multicolumn{4}{|c|}{ Rate Of Degradation In gm/ Moisture Content In gm/day } \\
\cline { 2 - 5 } & $\mathbf{7}^{\text {th }}$ & $\mathbf{1 4}^{\text {th }}$ & $21^{\text {st }}$ & $\mathbf{2 8}^{\text {th }}$ \\
\hline \multirow{2}{*}{$\mathrm{N}$} & 0.19 & 0.21 & 0.16 & 0.14 \\
\hline $\mathrm{BC}$ & 0.10 & 0.14 & 0.02 & 0.01 \\
\hline $\mathrm{ABC}$ & 0.04 & 0.07 & 0.13 & 0.10 \\
\hline $\mathrm{FC}$ & 0.09 & 0.08 & 0.07 & 0.12 \\
\hline $\mathrm{AFC}$ & 0.02 & 0.04 & 0.06 & 0.08 \\
\hline
\end{tabular}

Figure 2: Amylase activity graph



Figure: 3: Standard Glucose Concentration Curve



3. Estimation of Protein Concentration

4. Estimation of Reducing Sugar Concentration high

5. Antioxidant Activity
Table 5. Standard Glucose concentration curve

\begin{tabular}{|l|c|c|}
\hline Test Tube & $\begin{array}{c}\text { Standard Solution } \\
\text { Of Glucose (ug/ml) }\end{array}$ & $\begin{array}{c}\text { Optical Density } \\
\text { (At 540 Nm) }\end{array}$ \\
\hline 1 & 500 & 0.01 \\
\hline 2 & 2500 & 0.015 \\
\hline 3 & 5000 & 0.03 \\
\hline 4 & 7500 & 0.045 \\
\hline 5 & 10,000 & 0.06 \\
\hline
\end{tabular}

RESULTS AND DISCUSSION

Enzymes are large biological molecules responsible for the thousands of metabolic processes that sustain life. They are important product obtained for human needs from several sources are generally used in industries. An enzyme remains a major cost factor for the lignocellulose fuels and chemical industries. Enzymatic screening carried out on specific selective medium of microbes. Bacillus subtilis gives clear zone of inhibition after addition of iodine solution on starch agar i.e. it shows positive amylase activity. The positive cellulase activity screened on Carboxymethyl cellulose agar. Clear zone around growth after addition of Congo red dye solution on CMC agar given by E. coli, B. subtilis and A. niger. The experimental sample $\mathrm{N}$ shows highest degradation rate at high acidic condition and moisture content after 28th day. A colour changes from light green to Blue green at pH 8.5 and the volume reduces to $18 \mathrm{gm}$. with $7 \mathrm{gm}$. moisture content (Krishna et al., 2016). 
Table 6. Cellulase Activity Chart

\begin{tabular}{l|c|c|c|c|}
\hline \multirow{2}{*}{$\begin{array}{l}\text { Test } \\
\text { Sample }\end{array}$} & \multicolumn{4}{|c|}{ Rate Of Degradation In gm/ Moisture Content In gm/day } \\
\cline { 2 - 5 } & $\mathbf{7}^{\text {th }}$ & $\mathbf{1 4}^{\text {th }}$ & $\mathbf{2 1}^{\text {st }}$ & $\mathbf{2 8}^{\text {th }}$ \\
\hline \multirow{2}{*}{ Normal } & 0.02 & 0.03 & 0.04 & 0.01 \\
\hline BC & 0.06 & 0.05 & 0.04 & 0.02 \\
\hline ABC & 0.04 & 0.06 & 0.03 & 0.02 \\
\hline FC & 0.03 & 0.02 & 0.01 & 0.01 \\
\hline AFC & 0.01 & 0.02 & 0.03 & 0.02 \\
\hline
\end{tabular}

Figure 4: Cellulase activity graph

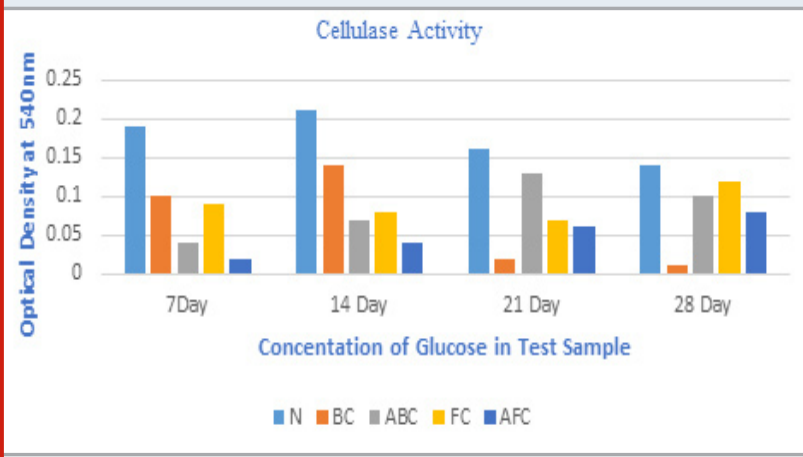

Table 7. Standard Glucose concentration curve

\begin{tabular}{|l|c|c|}
\hline Test Tube & $\begin{array}{c}\text { Standard Solution } \\
\text { Of Glucose (ug/ml) }\end{array}$ & $\begin{array}{c}\text { Optical Density } \\
\text { (At 750 Nm) }\end{array}$ \\
\hline 1 & 200 & 0.13 \\
\hline 2 & 400 & 0.20 \\
\hline 3 & 600 & 0.40 \\
\hline 4 & 800 & 0.53 \\
\hline 5 & 1000 & 0.70 \\
\hline
\end{tabular}

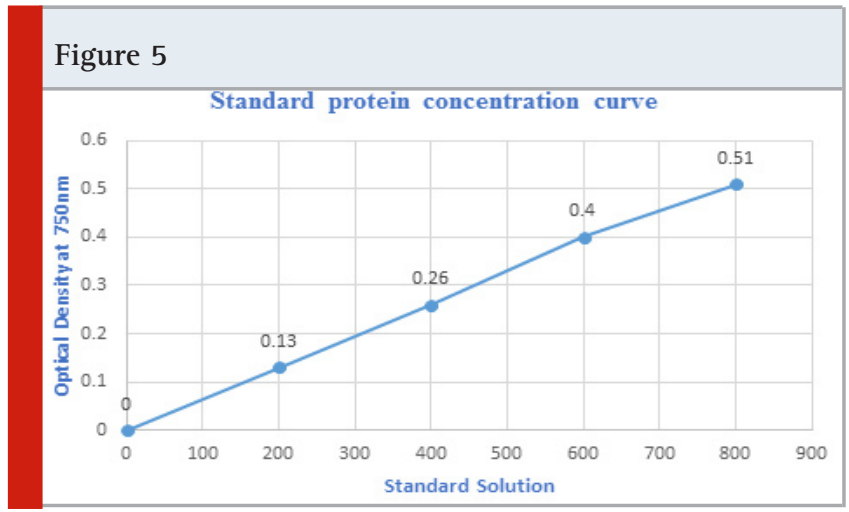

Table 8. Cellulase Activity Chart

\begin{tabular}{l|c|c|c|c|}
\multirow{2}{*}{$\begin{array}{l}\text { Test } \\
\text { Sample }\end{array}$} & \multicolumn{4}{|c|}{ Rate Of Degradation In gm/ Moisture Content In gm/day } \\
\cline { 2 - 5 } & $\mathbf{7}^{\text {th }}$ & $\mathbf{1 4}^{\text {th }}$ & $\mathbf{2 1}^{\text {st }}$ & $\mathbf{2 8}^{\text {th }}$ \\
\hline \multirow{N}{*}{$\mathrm{N}$} & 0.31 & 0.17 & 0.11 & 0.07 \\
\hline $\mathrm{BC}$ & 0.01 & 0.28 & 0.08 & 0.05 \\
\hline $\mathrm{ABC}$ & 0.18 & 0.17 & 0.15 & 0.11 \\
\hline FC & 0.01 & 0.13 & 0.18 & 0.26 \\
\hline AFC & 0.16 & 0.08 & 0.04 & 0.01 \\
\hline
\end{tabular}

Various assay carried out to measure the amount of enzymes and other nutrients present in selected test samples by taking standard. After incubation period, it was observed that Amylase concentration was increases after 14th day of incubation. In test sample $\mathrm{N}$, The maximum amylase production was observed on 14th day of incubation which is $330 \mathrm{ug} / \mathrm{ml}$.BC shows maximum amylase concentration of $220 \mathrm{ug} / \mathrm{ml}$ within 14 days of incubation. But in case of FC it was just $200 \mathrm{ug} / \mathrm{ml}$ after 
21days of incubation. ABC and AFC possess $200 \mathrm{ug} / \mathrm{ml}$ after 21th day and $130 \mathrm{ug} / \mathrm{ml}$ after 28th day of incubation respectively (Laufenberg et al., 2003).

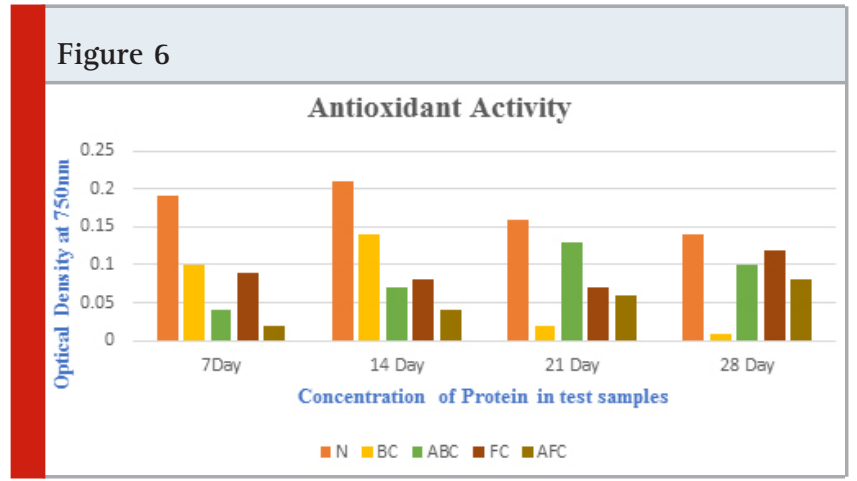

Table 9. Standard Glucose concentration curve

\begin{tabular}{|l|c|c|}
\hline Test Tube & $\begin{array}{c}\text { Standard Solution } \\
\text { Of Glucose (ug/ml) }\end{array}$ & $\begin{array}{c}\text { Optical Density } \\
\text { (At 520 Nm) }\end{array}$ \\
\hline 1 & 200 & 0.13 \\
\hline 2 & 400 & 0.20 \\
\hline 3 & 600 & 0.40 \\
\hline 4 & 800 & 0.53 \\
\hline 5 & 1000 & 0.70 \\
\hline
\end{tabular}

The substrate Carboxy methyl cellulose required for cellulase production. The maximum cellulase production observed after 21th day of incubation in $\mathrm{N}$ and AFC, which is $6700 \mathrm{ug} / \mathrm{ml}$ and $5000 \mathrm{ug} / \mathrm{ml}$ respectively. Both BC and FC shows maximum cellulase production is $10000 \mathrm{ug} / \mathrm{ml}$ after 7 th day. ABC shows substrate utilization is $5000 \mathrm{ug} / \mathrm{ml}$ after 21th day of incubation. The maximum protein Concentration observed in $\mathrm{N}$ test sample is $460 \mathrm{ug} / \mathrm{ml}$ after 7 th day of incubation. $420 \mathrm{ug} /$ $\mathrm{ml}$ concentration observed in test sample BC after 14th day and $270 \mathrm{ug} / \mathrm{ml}$ in test sample $\mathrm{ABC}$ after 7 th day of incubation. Test sample FC and AFC Shows maximum protein concentration are $390 \mathrm{ug} / \mathrm{ml}$ after 28th day and $240 \mathrm{ug} / \mathrm{ml}$ after 7th day of incubation period.

Figure 7

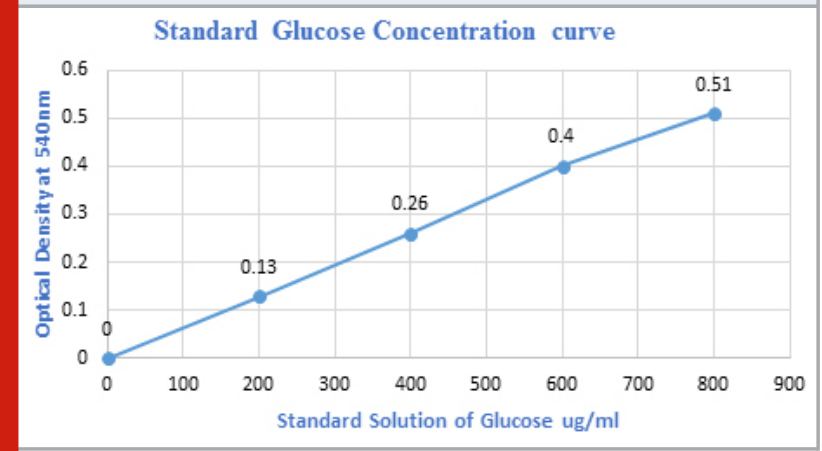

Table 10. Cellulase Activity Chart

\begin{tabular}{l|c|c|c|c|}
\multirow{2}{*}{$\begin{array}{l}\text { Test } \\
\text { Sample }\end{array}$} & \multicolumn{4}{|c|}{ Rate Of Degradation In gm/ Moisture Content In gm/day } \\
\cline { 2 - 5 } & $\mathbf{7}^{\text {th }}$ & $\mathbf{1 4}^{\text {th }}$ & $\mathbf{2 1}^{\text {st }}$ & $\mathbf{2 8}^{\text {th }}$ \\
\hline \multirow{N}{*}{$\mathrm{N}$} & 0.13 & 0.07 & 0.05 & 0.01 \\
\hline BC & 0.17 & 0.13 & 0.05 & 0.04 \\
\hline ABC & 0.09 & 0.04 & 0.03 & 0.01 \\
\hline FC & 0.13 & 0.08 & 0.03 & 0.02 \\
\hline AFC & 0.05 & 0.03 & 0.02 & 0.01 \\
\hline
\end{tabular}

Figure 8



Table 11. Standard Glucose concentration curve

\begin{tabular}{|l|c|c|}
\hline Test Tube & $\begin{array}{c}\text { Standard Solution } \\
\text { Of Glucose (ug/ml) }\end{array}$ & $\begin{array}{c}\text { Optical Density } \\
\text { (At 700 Nm) }\end{array}$ \\
\hline 1 & 100 & 0.10 \\
\hline 2 & 300 & 0.27 \\
\hline 3 & 500 & 0.45 \\
\hline 4 & 700 & 0.70 \\
\hline 5 & 1000 & 0.90 \\
\hline
\end{tabular}




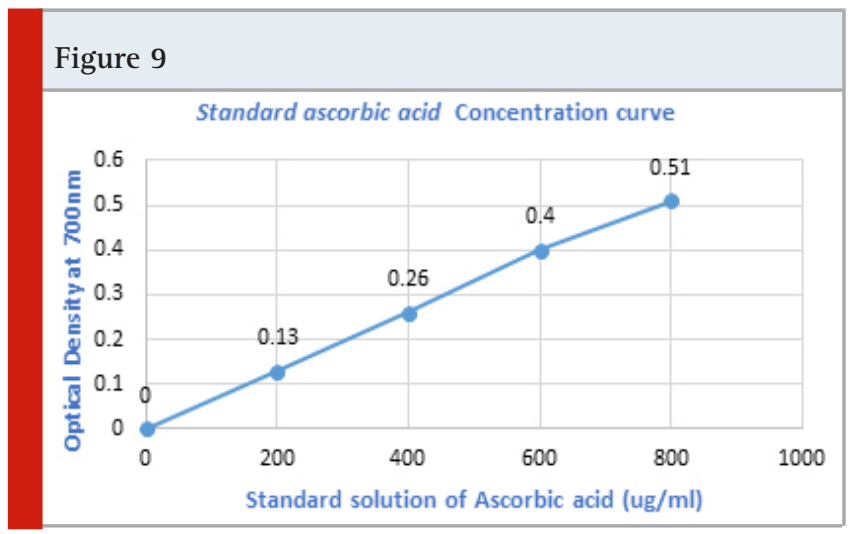

Table 12. Cellulase Activity Chart

\begin{tabular}{l|c|c|c|c|}
\hline \multirow{2}{*}{$\begin{array}{l}\text { Test } \\
\text { Sample }\end{array}$} & \multicolumn{4}{|c|}{ Optical Density at $700 \mathrm{~nm}$ [days] } \\
\cline { 2 - 5 } & $\mathbf{7}^{\text {th }}$ & $14^{\text {th }}$ & $21^{\text {st }}$ & $\mathbf{2 8}^{\text {th }}$ \\
\hline \multirow{2}{*}{$\mathrm{N}$} & 0.34 & 0.53 & 0.57 & 0.60 \\
\hline $\mathrm{BC}$ & 0.64 & 0.41 & 0.32 & 0.31 \\
\hline $\mathrm{ABC}$ & 0.79 & 0.83 & 0.51 & 0.40 \\
\hline $\mathrm{FC}$ & 0.52 & 0.41 & 0.26 & 0.24 \\
\hline $\mathrm{AFC}$ & 0.72 & 0.33 & 0.26 & 0.22 \\
\hline
\end{tabular}

Figure 10

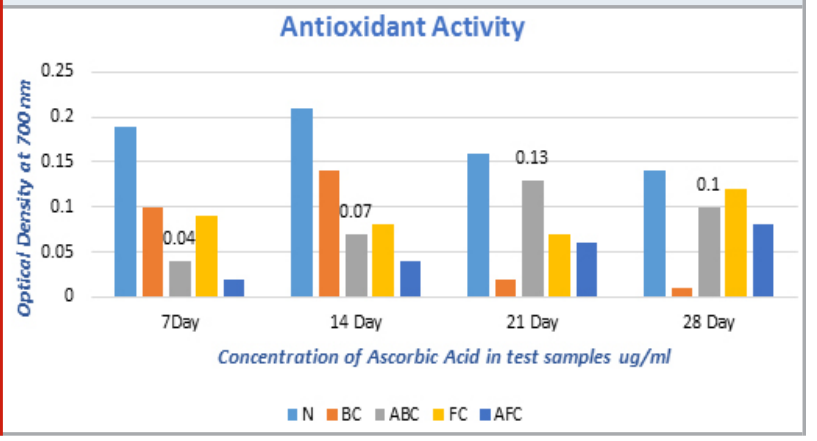

The high reducing sugar concentration observed in test sample N, BC and ABC are $1800 \mathrm{ug} / \mathrm{ml}, 2350 \mathrm{ug} /$ $\mathrm{ml}$ and $1250 \mathrm{ug} / \mathrm{ml}$ after 7th day of incubation period. The test sample $\mathrm{FC}$ and $\mathrm{ABC}$ shows maximum glucose concentration are $1800 \mathrm{ug} / \mathrm{ml}$ and $700 \mathrm{ug} / \mathrm{ml}$ after 7 days of incubation period. Antioxidant activity of test sample estimated calorimetrically at $695 \mathrm{~nm}$, it shows maximum antioxidant production after 7th day of incubation from BC, FC, AFC are $710 \mathrm{ug} / \mathrm{ml}, 570 \mathrm{ug} /$ $\mathrm{ml}, 800 \mathrm{ug} / \mathrm{ml}$ respectively. The maximum antioxidant production by Control and ABC shows $660 \mathrm{ug} / \mathrm{ml}$ after 28th day and $930 \mathrm{ug} / \mathrm{ml}$ after 14th day of incubation. The present study concluded that Microbial conversation of vegetables waste to bio fertilizer is a feasible and potential technology in the future to maintain the natural resources and to reduce the impact on environmental quality. It is a simple biotechnological process of composting in which certain species of bacteria are used to enhance the process of waste conversion and produce a better end product (Mussatto et al., 2011; Novinsak et al., 2011; Pothiraj \&t Eyini 2007; Panda et al., 2016; Steger et al., 2017).

\section{REFERENCES}

Bird, R., and Hopkins, R. H., (1954). 'The action of some alpha- amylases on amylase', Biochemical Journal, Volume 56(1), 86-99

Bruckner, M, Gram Sraining Procedure, (2016). Microbial Life Educational Resources, https:// serc.carlenton. edu/18370 Nov. 3

Chapman -Smith, A, Cronan Jr , J.E., (1999). 'Molecular biology of biotin attachment to proteins', The journal of nutrition, volume 129, pages 477S484S, https:// doi.org/10.1093/jn/129.2.4.77S

Gautam, S, Bundela, P, Pandey, A, Jamaluddin, Awasthi, M and Sarsaiya, S (2012). 'Diversity of cellolytic microbes and the biodegradation of municipal solid waste by a potential strain', International journal of microbiology, volume, Article ID 325907,pages 12,doi: 10.1155/20121325907,2012

Gautam, S, Bundela, P, Pandey, A, Awasthi, M and Sarsaiya, S, (2010). 'Microbial consortium for effective composting of municipal solid waste by enzymatic activities', Journal of applied science in environmental sanitation, 5(3), 301-308

Indumathi, D, April (2017). Microbial conversion of vegetable waste for biofertilizer production, Journal of Biotechnology and Biochemistry, Department 
of zoology, Vellalar college for women, Erode-12, Tamilnadu, IOSR

Ingale, S, Joshi, S and Gupte, A (2014). 'Production of bioethanol using agricultural waste: Banana pseudo stem', Brazilian Journal of Microbiology, 45(3), 885892,

Doi : 1590151517-83822014000300018

Janarthanan, R, Prabhakaran, P and Ayyasamy, P, (2014). 'Bioremidiation of vegetable waste through biomanuring and enzyme production', International Journal of Current Microbiology and Applied Science, Volume 3, Issue 3, pages 89-100

Krishna Rao, M , Sivagnanam, S and Syed. F, (2016). 'Isolation, Characterization and Identification of predominant microorganisms from agro waste', Department of Industrial biotechnology Bharath university, Chennai, India, Scholars Research Library, Der pharmacia Lettre, 8(5), 79-86.

Laufenberg, G, Kunz, B and Nystroem, M, (2003). 'Transformation of vegetable waste into value added products', Bioresource technology, 87(2), 167-198

Doi: 10.1016/50960- 8524 (02) 00167-0

Mussatto, S, Machado, E, Carneiro, L and Teixeria, J, (2012). 'Sugar metabolism and ethanol production by different yeast strains from coffee industry waste hydrolysis', Applied Energy, Volume 92, Pages763-768, Doi : 10.1016/j.apenergy.2011.08.020

Novinsak, A, Surette, C, Allain, C, Filion, M, (2008). 'Application of molecular technologies to monitor the microbial content of biosolids and composted biosolids', Water Sci Technol, 57: 471-477, Doi : 10.2166/wst, 2008.019

NHB (2013), Indian horticulture database, Ministry Of agriculture, Government of India, Gurgaon

Pothiraj, C and Eyini, M, (2007). 'Enzyme activities and substrate degradation by Fungal Isolates on Cassava waste during solid state fermentation', Microbiology, 35(4), 196-204

Doi: 10.4489/MYC0.2007.35.4.196

Panda, S, Mishra, S, Kayitesi, E and Ray, R, , (2016). April, 'Microbial Processing of fruit and vegetable waste for production of vital enzymes and organic acids, biotechnology and scopes' 146, 161-72, Doi: 10.1016/j. envres.2015.12.035

Steger, K, Sjogren, A, Jarvis, A, Jansson, J and Sundh,
I, (2007). 'Development of compost maturity and Actinobacteria populations during full scale composting of organic household waste', Journal of Applied Microbiology, 103, 487-498

Doi: 10./1111/j.1365- 2672.2006.03271.

Sanmanee, N, Panishkan, K, Obsuwan, K, Dharmvanij, S, 'Study of compost maturity during humification process using UV- Spectroscopy', World Acad Sci Eng Technol, 2011, 80, 403-405

Sarkar, P, Meghvanshi, M, Singh, R, (2011). 'Microbial Consortium: A New Approach in Effective Degradation of Organic Kitchen Wastes', International Journal of Environmental Science and Development, Vol.2, No.3 Sethi, S, Datta, A, Gupta, B, Gupta, S, 'Optimization of Cellulase Production from Bacteria Isolated from Soil' Department of Biotechnology, Dr. B. Lal Institute of Biotechnology, Malviya Industrial Area, Malviya Nagar, Jaipur 302017, India,

Unakal, C, Kallur, R, and Kaliwal, B, (2012). 'Production of alpha amylase using banana waste by bacillus subtilis under solid water fermentation' European Journal of Experimental Biology, 2(4), 1044-1052

Umsakul, K, Dissara, Y and Shrimuang, N, (2010). 'Chemical physical and microbiological changes during composting of the water hyacinth', Pakistan Journal of Biological Science, Volume 13, Issue 10, Pages 985-992, Doi : 10.3923/pjbs.2010.985.992

Veeramani, Kumar, N and Kavitha, (2017). 'Review on Bacterial biodegradation of municipal solid waste management in India', International Journal of Innovative Research in Science, Engineering and Technology, Tamilnadu, India, Volume 6, Issue 1

Wijngaard, H, Roble, C and Brunton, N, September (2009). A survey of Irish fruit and vegetable waste and by products as a source of phenolic antioxidants', Food chemistry, Volume 116, Issue 1, Pages 202-207, Doi. 10.1016/j.foodchem.2009.02.033

Wu, L and Ma, L, 'Relationship between compost stability and extractable organic carbon', J Environ Qual, (2002)., 31, 1323-1328, Doi: 2134/jeq 2002.1323.

Yoshida, S, Hiraga, K, Takehana, T, Taniguchi, I, Yamaji, H, Maeda, Y, Toyohara, K, Miyamota, K, Kimura, Y and Oda, K, 'A bacterium that degrades and assimilates poly (ethylene terephthalate)', Volume 351, Issue 6278, Pages 1196-1199 Doi: 10.1126/science.aad6359. 